\title{
The State as a Battlefield
}

It was Saturday afternoon. I was sitting outside one of the cafés in Zona $\mathrm{F}$ in 23 de Enero with Miche and Adrian, having a beer. Both were experienced revolucionarios, having been trained as cuadros (cadres) in the revolutionary youth organization Frente Francisco de Miranda. For several years, they had worked in different government institutions echandole bolas (lit: throwing in balls, fig: working hard). For them, working with the state was a political and ideological task. Both believed in the necessity of profound changes and in the paramount importance of changing the state from the inside in order to create a new Bolivarian state and society.

Both Miche and Adrian had grown up in a barrio and were high-school dropouts, living with their single mothers and extended family, forced to start working at an early age. Even if they had always had an ideological affinity with anti-imperialist and popular sector struggles, they had not become really politicized until Chávez arrived on the scene after the 1998 election. At the time, they were part of the first wave of new political organizations: Miche was part of the Bolivarian Circles, and Adrian of a cultural group in his community. He made magic happen with his African drums, and the group he was a part of was occasionally hired as "musical entertainment" for those who wanted a "folkloric touch" at high-class parties in the eastern part of the city.

Both Miche and Adrian had become radicalized after the 2002 coup. They were part of the popular resistance during those chaotic days, driving around on motorbikes and mobilizing people to demand Chávez's return. Afterward, both of them went to Cuba with Frente Francisco de Miranda. 
Frente Francisco de Miranda is a youth organization that was established by a joint agreement between Fidel Castro and Hugo Chávez in 2003 in order to educate a new generation of Venezuelan civil servants. The students-mostly young people-were flown to Cuba where they lived on campuses while following an intense educational program in history, political science, public administration, economics, political ideology as well as personal development. The organization describes itself as:

A political organization-disciplined, anti-imperialist, dynamic and organized: fundamental in the struggle for eradicating poverty in all its manifestations and for achieving social equality in Venezuela. It is an instrument that supports the missions and contributes to the successful development of the programs incited by the Revolutionary Government, to benefit the most humble classes, in correspondence with the Bolivarian ideal and the thinking of Comandante Chávez. We are in every corner of the country day by day, giving our lives for achieving a more just society, filled with solidarity, fraternity and dedicated to disinterested humanitarian aid without expecting nor receiving anything in return apart from the prosperity of our country. (Frente Francisco de Miranda n.d., author's translation from Spanish)

The educational program was free of charge, and the students received a minor scholarship for personal costs. For many poor youth, this was their first trip outside Venezuela, and for rural students, sometimes their first trip to central Venezuela. The classes in Cuba were called avanzadas, and the intense period of close-quarter living in dormitories and around-the-clock studying-often over several months-generated strong sentiments of collectivity and friendships as well as a close identification with "their" avanzada class, which were maintained in the years even as Frente Francisco de Miranda as a mass movement as such fell more or less apart (see below).

Miche and Adrian were part of one of the first avanzadas, and because they displayed talent, both of them returned to Cuba for shorter and more selective classes in administration and leadership. Back in Venezuela they were involved in building the Frente's headquarter in Gato Negro, Catia, as well as working with several government ministries.

When I met them, they were both working in Fundacomunal. Miche was planning on quitting: he had had enough. "I feel like an accomplice. I can no longer justify that I have to answer, 'I don't know' to my community," he said. "His community" was the area where he worked with the communal councils. He had long been frustrated because those higher up in the system in Fundacomunal helped neither him nor the community, 
and he was the one who had to face the members in the communal council every week with an "I don't know what is happening."

Adrian agreed that it was difficult to defend the status quo. They witnessed revolutionary fervor being replaced by struggles for power, inefficiency and opportunism, which represented a serious threat to the political future of the Bolivarian revolution. The old vices of the state inherited from the Fourth Republic had not only remained, but they had also contaminated the revolutionary process from within.

They were both critical of their workplace, as a proper critical revolutionary in their opinion should have been, but they both knew that if they voiced their frustrations too loudly, they would get in trouble. It had happened to them both before. Miche had denounced corruption in another organization and had been pushed out, though very subtly. Adrian had quit a former job because he was treated badly by a superior with friends in high places and had suddenly found himself in a situation where he had great difficulty in getting a new job. Because of their attitudes, they had not been allowed to advance despite their having been chosen as "selected potential leaders" when they first started.

Both Adrian and Miche were tired of all the shortcomings within the political administration and state bureaucracy. It also filled them with profound sadness. They both described the early years after 2003 as the best moment of their lives. They had been part of the wave of revolutionary spirit and new policies in the wake of the 2002 coup and had participated in making wonderful things happen. Both of them had traveled across the country to remote countryside villages and backward middle-of-nowhere sites, day and night, and had helped setting up the missions and issuing identity cards through Misión Identidad. ${ }^{1}$ They had sacrificed romantic relationships and family, a decent salary and a good night's sleep for years. And they weren't the only ones. Thousands of youths had become mobilized. There had really been a mass movement, a mass enthusiasm, a sense of family. And now they felt that this enthusiasm to a large extent had withered away.

Much of this was due to the bureaucracy, which they viewed as the tranca de piedra (sand in the machinery) of the revolution. Adrian was waiving his beer as he was presenting his favorite metaphor to describe what was happening: the hamburger bread and the meat. The community was the bottom piece of bread, and the president was the top piece of bread, where the policies benefiting the communities were emerging from. In the middle you had a huge hamburger which was the bureaucracy, filled with vicios (vices). Because of this dysfunctional bureaucratic hamburger, 
the policies that were meant to benefit the communities didn't filter down the way they were supposed to. And that was the biggest threat to the revolution, Miche and Adrian agreed on that.

In the foregoing chapter, I started my exploration of community politics in the barrios. I analyzed the ways in which popular struggle played out within what I have termed a Bolivarian space: a political space of interaction between state and grassroots movements, drawing on templates of popular sovereignty and the state's historical debt to the poor. In the following two chapters, I will continue my inquiry into the political and everyday encounters between popular sector communities and the Venezuelan state under Chávez. The broader analytical ambitions with these chapters are twofold: one is to understand state practices and state dynamics from the pre-Chávez era, and how these vestiges were contested, challenged and reproduced during the Chávez era. That is, I am interested in the political and temporal interface between the state of the Fourth Republic and the emerging state of the Fifth Republic. The second analytical ambition is to understand how the popular sectors pushed from below to transform the "old" state according to Bolivarian ideals, and to explore the strategies they used. At the heart of these processes were attempts to make "the state"we will come back to the theoretical implication of studying "the state" below-less opaque, less corrupt, less patronizing, less hierarchic, less clientelistic, and more open to popular demands, knowledges and socialities.

I do not claim that these negative dynamics and characteristics attributed to the Venezuelan state are unique to Venezuela. Rather, Latin American states-to various degrees - share a host of similar characteristics. This has its root in their genesis as colonial and later post-colonial states, and how processes of state formation were taking place in societies sharing many similar features. Thus, in many respects, this account says something about Latin American state formations in general, and many of the challenges encountered by Bolivarian activists are parallel to those of their fellow comrades in other countries (e.g., see Lazar 2008). However, the ethnographic moment and context studied here is unique in the sense that it represents a particular historical constellation of political ideas and social forces: that is, the Bolivarian process. Through exploring the frictions, contradictions and struggles emerging as the ideals of the Bolivarian process rubbed against ingrained social practices and heterogeneous interest 
and ideologies, we are better equipped to understand both the Bolivarian process' particularities and the inherent complexities in processes of political and social change.

\section{TheOrizing THE StaTe}

Adrian and Miche's story tells a tale of a short-term political trajectory within the early years of the Bolivarian revolution. It also conveys a deeper script about the quest to transform not only state praxis, that is, how the state functions, but also to change the meaning of the relationships between society and the state.

Scholarly inquiries into the state throw up a host of theoretical implications. Of particular relevance to our context is, how can we understand the relationship between the state and society, and how do we understand power and resistance both inside and outside the state? Anthropological theory-production about the state has problematized and criticized Foucauldian and Weberian approaches to the state that pose state and society in a dichotomist relationship. For Foucauldian-inspired scholars, the state derives its power and its appearance as a bounded totality through the aggregated diffusion of impersonalized rule, institutions and procedures - that is, governmentality (e.g., see Foucault 1991; Mitchell 2006). To Weberian scholars, "the state appears monolithic to society because its work follows certain impersonal, rational and standardized routines which give it a sui generis quality" (Neuman 2005:195). In both cases, the state appears as a bounded locus of power, set apart from society.

Anthropological scholars on the other hand, have argued that how the state appears, and how people view the state and position themselves in relation to it, is essentially a case of empirical inquiry. Gupta (1995), for example, asks whether the Western legacy of universalizing a dual cultural construction of state-society relations stands up to scrutiny in the face of "incommensurable cultural and historical contexts" (Gupta 1995:214). Drawing on ethnography from India, he argues that "we should leave open the analytical question as to the conditions under which the state does operate as a cohesive and unitary whole" (Gupta 1995:229). Nuijten (2003) makes a similar argument when she teases out a duality in the way Mexican peasants both engage with and imagine the state. Power is not an abstract formalized rule, but rather a myriad of changing strategies that are personalized and continuously reinvented (Nuijten 2003:120). At the same time, she argues that governmental techniques such as stamps, maps 
and official terminology contribute to the preservation of the myth of bureaucratic rule and the appearance of a coherent system (Nuijten 2003).

\section{Hegemony and Practice}

Anthropologists perceive of the state as a set of institutions, strategies and practices as well as an idea and ideological construct (see also Abrams 1988 [1977]; Blom Hansen and Stepputat 2001; Krohn-Hansen and Nustad 2005; Sharma and Gupta 2006). This is important for our ethnographic explorations, because it allows us to understand the Venezuelan state from various angles. "The Magical State" as a megamonolithic representation of power as sketched out by Coronil as well as the highly personalized inroads and dynamics within the Venezuelan state bureaucracy that we have already started to analyze are two valuable analytical inroads. However, the implicit conceptualization of the state and its relationship to society undercutting popular sector agency is also of crucial importance to our exploration. At times, people invoked an imagery of the Venezuelan state as a monolithic apparatus. This imagery was shaped by the state's projection of itself-its imaginary state-craft-as well as by subjective encounters through which the state had rendered visible its exclusionary boundaries. At the same time, through its lack of Weberian systems of governance, it was also perceived of as a domain with the potentiality to be penetrated through social relations and practices traversing state-society boundaries. Moreover, people understood the state as a condensed site of power stratifying and organizing the diffusion of power throughout the rest of society. And, vice versa, as an instrument of power that different groups in society tried to seize in order to consolidate their power on other social, economic and political arenas. That is, the state is an amorphous entity, appearing as a different beast in different contexts and from different viewpoints. This is reminiscent of what Gupta quotes Donna Haraway on stating, "there is obviously no Archimedean point from which to visualize 'the state,' only numerous situated knowledges" (Gupta 1995:229).

Valencia argues that in order to understand the slogan "We Are the State!" as often uttered by Chávez's grassroots supporters, we need to do a "critical rereading of Gramsci's notion of hegemony and its relationship to culture" (Valencia 2015:17). His contribution is important because it highlights that the state is a site for the construction of hegemony. The popular sectors' attempt to transform the state from below was derived from a keen understanding of the state's role in shaping how "various relationships 
of subordination work" (Crehan 2002:105). As Scott (1985) has showed, resistance can come in numerous forms, open and covert, creatively reinvented and transformed in the course of different contexts and changing contour of domination. In the context of the Bolivarian process, popular sector activists were faced on the one hand with a seemingly benevolent state that professed - at the level of government ideology-that the state was theirs to appropriate and transform. On the other hand, people were keenly aware that the de facto transformation of the state implied challenging both concrete practices and institutionalized networks of power-both sympathetic to and in opposition to the government-as well as the cultural hegemony ingrained in the state. This duality, of the personalization and porousness of state power at the level of everyday practices, as well as the imagery of the state as a site of domination, is central for understanding how the state became an epicenter for struggle during the Bolivarian process.

\section{TAKING OVER THE STATE (?)}

The picture becomes even more complicated when we try to understand how and to what extent the Chávez government was actually able to assert power over the state. As Hansen and Stepputat note:

Political power does not mean that a new government can change institutional routines overnight or that social practices within the bureaucracy can be easily modified. The state is an enormous and amorphous mechanism that functions along a whole range of discrete and often self-perpetuating logics, bereft of any unifying an encompassing rationale. (Blom Hansen and Stepputat 2001:28)

They suggest that in order for a new political regime to successfully reach its objectives, it needs to design and implement a fairly coherent state project that involves "thoroughgoing institutional reforms and a certain reinvention of the state" (Blom Hansen and Stepputat 2001:29). However, more often than not, this does not happen, implying that "most contemporary societies remain governed by yesterday's administrative systems and procedures" (Blom Hansen and Stepputat 2001:29). The consequences of multiple "incomplete overhauls" by new regimes are that state systems are shaped by multiple sets of sediments of governance:

Each new regime builds a number of new institutions and nurses particular areas with greater care and zeal, often reflecting the larger ideological for- 
mation and communities out of which they have emerged. (Blom Hansen and Stepputat 2001:30)

Moreover, different parties cultivate particular ties of loyalties and patronage to different parts of the state system, leading to an additional "zonification" and fragmentation of the bureaucratic apparatus (Blom Hansen and Stepputat 2001:30). These insights are crucial for our context. Popular politics and state reforms in the Chávez era were taking place within a highly conflictive terrain, with a variety of actors and interests both within and outside the realm of the state. In addition, the government built up a host of new institutions and structures, exactly in order to "by-pass" the pre-existing structures that they knew were extremely difficult to reform and gain control over. This produced an additional fragmentation and "zonification" of the state that made the enactment of government reforms a challenge.

Indeed, an inquiry into the Venezuelan bureaucracy to a certain extent debunks the popular myth that Chávez and his government wielded excessive power over the state bureaucracy. The Venezuelan state is historically imbued with "non-Weberian" dynamics in the sense of being a site of personalized and highly fallible bureaucratic practices. These practices became even more complicated as the Venezuelan state under Chávez became a conflictive site for new and old networks of power, some resisting and some reproducing entrenched state practices, and all of them intensely competing for power. These insights provide a clearer picture of why political reforms enacted from above were so difficult to enact. It also helps us understand why popular sector activists insisted on popular struggle as the key to the advancement of the Bolivarian process. The Venezuelan state would not transform itself on its own. It could only be transformed through sustained pressure and popular struggle from below in a prolonged Gramscian war of position as well as war of maneuver.

\section{Structure, Agency and Habitus}

Inquiries into human interaction with external structures will always bring up the eternal debate about the relationship between structure and agency. It will become clear from my ethnographic exploration that I attribute to the Venezuelan state a considerable power over reproducing habitus (Bourdieu 1979), even in the midst of radical change. In Bourdieu's own words: "the habitus, the product of history, produces individual and 
collective practices, and hence histories, in accordance with the schemes engendered by history" (Bourdieu 1979:82).

However, even as the schemes of the Venezuelan state as engendered by history, to paraphrase the quote above, appear to be resilient in many ways, I will illustrate the micro-processes of change taking place in different fields through the flow of new policies, reforms, discourses and configurations of new political and social actors. In Nuijten's interpretation of Bourdieu's concept of field

agents and institutions constantly struggle, according to the regularities and the rules constitutive of this space to appropriate the specific products at stake in the game. Those who dominate in a given field are in a position to make it function to their advantage, but they must always contend with the resistance, the claims, the contention, of the dominated. (Nuijten 2003:13)

Moreover, in different agents' quests for conquering that field, they deploy the forms of capital (Bourdieu 1986) that correspond to that field. The historical conjuncture and the processes at play that are analyzed in this book might be cast as a reorganization of fields, and forms of capital that correspond to them, as different social actors tried to appropriate new political spaces within the Bolivarian process. Concretely, the discursive and political potency of the ethos of "popular power" constituted a new form of political and symbolic capital that was used in various ways by different actors to gain leverage, prestige and influence.

\section{Organizing Power (s)}

Wolf argues that if we want to understand power, we need to start with history and processes of organization of power. Organization, he argues, "sets up relationships among people through allocation and control of resources and rewards" (Wolf 1990:590). At the same time he cautions that organization is always at risk; as power balances shift and change, power never reaches its final form of organization (Wolf 1990:590). As I outlined in Chap. 2, the history of the organization of the Venezuelan state through different power arrangements can be captured through different time frames, each of them showing processes of continuities as well as discontinuities. ${ }^{2}$ This is also the case with the Chávez epoch.

Changes under the Chávez government, in spite of being frequently referred to as a "Bolivarian revolution," were not a revolutionary process, 
but a reformist one. While a true political revolution implies "a rapid, basic transformation of a society's political structures" (Thomassen 2012:683), the Chávez government left political structures intact or sought to reform them from within while simultaneously building new, parallel structures. ${ }^{3}$ New legislation invested new forms of responsibilities, ends and means into existing institutions, while new institutions were being created in order to implement political reforms. At the same time, the Venezuelan state apparatus was in many respects left unchanged, permeated by old (in parallel with the new) power structures, personnel and institutional practices. While these inter- and intra-institutional struggles-intrinsic to any process of regime change-were evident at the level of day-to-day politics, they also gave way to a new understanding of the battle for hegemony over the political domain played out between the "old state" and the ideal vision of the reformed Bolivarian state.

At the heart of this process was the popular day-to-day struggle for appropriating the political space that was opened up by new legislation, policies and political discourse. It is to the day-to-day reality that I will now turn. However, I believe that it is appropriate to start "from the top," with a broad overview of core issues related to the Venezuelan state system and how it relates to the broader process of political struggle and reconfigurations of power.

\section{Venezuelan State Practices}

As is common in other Latin American countries, the political and administrative bureaucracy in Venezuela is highly personalized and revolves around personal networks and alliances. A number of middle- and highlevel executive positions in the state and government apparatus (the socalled cargos 9.9) come with the clause that the new person in charge is allowed to change the key personnel working directly under her. These positions are called los cargos de confianza (positions of trust). That means that every time a key managerial position changes, the team supporting it also changes. That is why you often hear employees saying: "Yo entré por..." [I entered through...], meaning that you were brought in by the new person in charge. Moreover, if a new political actor wins an election to the parish, the municipal administration or governorship, the staff and service providers corresponding to the office is also by and large changed.

These practices have a range of implications. For one, they open up ample space for shady decision-making processes, including "corruption" 
(see Chap. 10), as positions of power are built around networks of people with loyalty to one or a set of managers or leaders. Moreover, the constant change of personnel implies a lack of knowledge transfer, as the people who were formerly staffing the office all leave, and the new ones do not necessarily know the area they will be working in. During the Chávez era there was a high turnover of both ministerial positions, a series of reorganizations of ministries and institutions, and a high degree of turnover in executive positions at various levels. I repeatedly saw how projects in the communities fell apart because there had been a change in positions, either in a political or in an administrative office. Often grassroots activists had spent a lot of time cultivating relations with political figures and state officials. But when positions were changed, their contact person and leverage also disappeared, and they had to start pushing to find another opening within the office they were dealing with.

Such practices also have the consequence that many state jobs are highly unstable, and people cultivate a range of different connections and networks within the state bureaucracy in order to ensure their future (see also Nuijten 2003). This creates strong and crosscutting alliances within the state system, which people also can rely on in order to get their job done. At the same time it should be said that internal recruitment procedures are not solely based on personal and political connections. Job performance does also play a role, though you often need someone to give you an opportunity and open the door for you; you need a door opener.

\section{The Practice of the Palanca}

In Venezuela, a door opener is called a palanca (lever). Palanca is an expression that denotes the practice of "knowing" someone on the inside in order to obtain something. That something may be a service, an operation at the hospital, a studying coupon at the university, a job or a bank credit. The practice of using a palanca implies that those who don't have a palanca will end up at the bottom of any priority list (e.g., a list of job applicants or a list of patients that have to undergo surgery). The social activist Rafael Gustavo González describes the culture of la palanca as follows:

The palanca doesn't only move the world, loosens up bolts and opens padlocks, but it gets anything. The culture of the palanca has been elevated in every sense to the point that the use and abuse of it has become com- 
monplace. Let's look at these expressions: Quite a trunk of a palanca you have! You surely got this with a palanca! Don't worry mum, I already got into university because I got a palanca! This is my friend Pepe who I told you about who has a really good palanca in the ministry! Look, Mary, don't forget to call Rosita who has a godmother who is friend of a doorman who has contact with the manager who serves you as a palanca! The palanca that I have is really good, I am sure to get that job. (González 2013)

The "acquisition-by-palanca" is part of virtually all spheres of society. It is possible to obtain things without a palanca, but a lot more insistence and effort are required. From an anthropological point of view, we can posit that doing a favor as a palanca amounts to an exchange similar to Marcel Mauss's (1954) gift. One the one hand, a palanca can be a formal agreement, even implicating an economic compensation. But it is most commonly tied to core social obligations inherent in close relationships between kin, friends and networks. Serving as palancas for one another, constitutes a vital part of how social relationships are forged. Thus, the practice of the palanca is part of an expanding web of networks of exchange - amounting to a time-diffuse but persistent presence of expectations of reciprocity. If I draw on your nephew's uncle's contact within the university in order get admitted into a master's program, it establishes me in an undefined relationship of reciprocity, with you or someone in your friend's networks.

Of course, this ties nicely with the common perception of Latin American states as infused with practices of corruption, nepotism, patronage, clientelism and amiguismo. I will not embark in that discussion here, as it would require going back to the historical context surrounding Venezuelan, and Latin American in general, state formations. Moreover, "corruption" will be thoroughly discussed in Chap. 10 where we will also look more closely into state practices and political imaginaries associated with corruption at large.

What I want to highlight however, is that the practice of the palanca has generated a state bureaucracy that is filled with spiderweb-like networks of loyalties and connections. Thus, while key political positions are appointed from the top (from the ministry), political power is not total. Rather, power is also filtered and diverted through co-existing or competing fiefdoms within the bureaucracy.

The palanca also creates dynamics whereby the state bureaucracy is filled with "fictitious positions" — positions that are created because some- 
one (sometimes unqualified and unmotivated) managed to get a job by using the right connections. This, as anyone who has dealt with Latin American bureaucracies can testify to, sometimes provides for bureaucratic encounters that makes you reach for both Kafka and Dante in order to conceptualize your sentiments. On a more serious note, it also evidently taps the state bureaucracy for resources and hampers public service performance.

\section{Fiefdoms AND NeTWORKS}

The sindicatos (labor unions) are also powerful actors within the public institutions. They control hiring, and backed by strong Venezuelan labor laws, they also make it highly unlikely for people they protect to be fired. To be protected by the union is also a matter of cultivating networks and palancas. To have a job with the Venezuelan state is extremely desirable. According to labor laws, people with a permanent employment contract within the state are entitled to new employment, should their job become redundant. Public employment also provides good welfare benefits in the form of health insurance, bonuses and pension. In some cases, public positions can even be transmitted from parent to child.

It is a common claim of the opposition that the Chávez government purged state institutions from opposition members. In my experience that is far from the truth. I have come across non-sympathizers to the government in all kinds of government institutions as well as in political offices, including the vice-ministry. As people often obtain positions through family, friends or a palanca, political preferences may not be relevant. Many people have also been employed by the state for years or decades, and cannot be removed because of Venezuelan labor laws. The union power networks often pre-date the Chávez era, and are powerful blocs that may, or may not, be effectively in opposition to the government. "The old personnel" pre-dating Chávez may also cultivate personal ties and networks with new leaders and power networks where political preferences are irrelevant or under-communicated. Personal, political and strategic networks are not necessarily determined by partisanship, and political power is far from hegemonic. Rather, the political field, in the broad sense, is guided by highly complex dynamics between new and old power networks, institutional mechanisms and legislation, and ingrained social practices traversing state-society boundaries. 


\section{The Labor Conflict in Fundacomunal}

A couple of years ago a labor conflict emerged in Fundacomunal. ${ }^{4}$ A new director, appointed by the head of Frente Francisco de Miranda, was put in charge of its main Caracas office, located in Catia. The new director was bent on reforming the institution from within, well aware of both its political importance-as the institution works closely with the communal councils-and its internal problematics, in the form of inefficiency, internal conflicts and, in some cases, incompetent and unmotivated personnel.

The institution's long history, originally founded by Acción Democrática in the 1960s, implied that it was filled with "superfluous" personnel. Some of the newcomers, who had entered the institution after the Chávez government assumed power, had also adopted a "non-conscientious" approach to their work. In the words of one of their former co-workers: "The only thing they did was to raise their pay-check and smoke marijuana in La Guaira." Eventually the new director fired a group of four to five people, from both the old and new guard. The group hired a lawyer, pulled strings within the institution, and went to the Ministry of Popular Power for Labour (Ministerio de Poder Popular Para el Trabajo) to complain over the alleged unlawful dismissal.

However, since early 2003, during the oil strike/lock out, the Chávez government had repeatedly renewed the decree of immobilidad laboral (labor immobility). The decree implied the temporary suspension of the right to dismiss employees, both in the private and in the public sector, unless the termination was on the grounds of a breach of contract (failure to fulfill work duties, criminal activities and so on). The reason for these measures was that during the strike, merchants and business owners from the opposition started to fire Chavista sympathizers en masse. In order to put an end to this, the immobilidad laboral was announced, and later renewed.

The highest authority in disputed dismissals is the Ministry of Popular Power for Labor. In the Fundacomunal firing case, the ministry of labor voted in favor of the discharged workers because the director had allegedly not filed the case properly. Fundacomunal was forced to compensate them for the unlawful dismissal with a year's salary, and to reintegrate them into the work force. The case had received massive public attention because the discharged workers had gone to the opposition media and complained, claiming to have been fired for political reasons. Eventually, the director was forced to resign from her position, officially, because she had not consulted her superiors before making the decision to dismiss 
them, unofficially, because of the negative publicity the event had brought upon Fundacomunal, and which she was held responsible for.

Thus, as this case shows, "Chavista-power" in state institutions was far from hegemonic. Rather, political intrigues, personal connections, laws and institutions steered events in one direction or another. Many people (bitterly) complained that adecos and copeyanos were more protected in the state institutions than the Chavistas, as the latter were newcomers and often on temporary contracts. The "old guard" on the other hand was safely protected by labor laws and long-established networks of power. It was a source of anger that, in labor conflicts, opposition supporters used the opposition media to give the impression that they were being fired for political reasons-while it might have been because of incompetence or other justifiable reasons for dismissal. The main opposition channel, Globovision, was in particular notorious for making a media circus out of any case that could portray the government as authoritarian or discriminatory.

As the government was wary of such media campaigns, people started claiming that the public institutions avoided firing people who should be fired, keeping opposition supporters in state jobs, from which they could continue hampering and subverting the Bolivarian process from within. As one government worker formulated it:

We have this fear of confronting the Right ... but if we don't transform [the state], if we don't have people that are really capacitated, people with a compromise and conviction capable to transform [the institutions], then we keep on maintaining the old, we keep on feeding the old, strengthening the old, and the old keeps on existing.

Government supporters, on the other hand, could be more easily dismissed or mistreated, as they would not "run off" to Globovision and complain, out of loyalty to the public image of the government.

\section{The Endogenous Right}

During the Fourth Republic, access to jobs in the state apparatus was based on allegiance to the dominant parties, Acción Democrática and COPEI. Doors were shut for those who were not affiliated with these parties and, to a large extent, these jobs were unavailable for the popular classes. In the course of the Bolivarian process, a new generation of state employees was formed consisting of people with a leftist or lower-class 
background. To a certain extent, this changed the rules of the state game, at the same time as it created a conundrum of highly conflictive and multifarious dynamics within the state and the political sphere of the Bolivarian space.

The old layers of the state bureaucracy were often referred to as los adecos (sympathizers/loyalists to Acción Democrática), or los cuartarepublicanos (those from the Fourth Republic). These were perceived of as saboteurs of the Bolivarian processes, not only because they might deliberately sabotage the execution of government's policy, but also because they were accustomed to a state culture of corruption, inefficiency and sloth. However, popular sector activists and conscientious public officials also felt that they were struggling on another front, namely against what was referred to as la derecha endogena (the endogenous right). La derecha endogena were people who might pose as fervent revolutionaries, but who in effect were more concerned with attending to their own ambitions and desires. Through not implementing reforms, plans and projects, they were sabotaging the process from within. Acting as if they supported the Bolivarian process, they could opportunistically plot their own schemes and build up their own (equally opportunistic) networks, squeezing outthrough dirty maneuvering - those who conscientiously sought to implement and act in accordance with "Bolivarian" principles and ideals. The presence of the endogenous right and opportunists within state institutions was perceived of as one of the greatest threats to the Bolivarian process, because it defamed the government in the eyes of the public and effectively sabotaged the advancement of popular sector struggles to appropriate the political space made available through government policy.

Additionally, people were concerned with the emergence of a new bureaucratic and political cast called the Boliburgesia (a combination of the words "Bolivarian" and "bourgeois"). Gossips of lavish spending, generous benefits and accumulation of private fortunes among "revolutionary leaders" were widespread both in the communities and among lower-rank employees. This was taken as evidence of how the old vices of the Venezuelan state-that is, the tradition of using state positions for private rent seeking - had gotten hold of revolutionary hearts and minds.

\section{The Fragmented State Arm}

Through these accounts of the inner dynamics of the Venezuelan state bureaucracy, a picture of a highly fragmented "executive arm" of government power emerges. The hierarchical structures, social practices and 
cultural meaning historically inscribed in the state bureaucracy was both reproduced and challenged, giving way to intense struggles both from within and the outside of the formal corridors of bureaucratic and political power. Constant battle between new and old networks of power, conflictual loyalties, personal interests and ideological positions evolved in the midst of attempts to implement new political reforms that at any rate would have demanded a lot of cohesive bureaucratic co-ordination and effort.

As I quoted Blom Hansen and Stepputat on saying above: "The state is an enormous and amorphous mechanism that functions along a whole range of discrete and often self-perpetuating logics, bereft of any unifying an encompassing rationale" (Blom Hansen and Stepputat 2001:28). Historically, the Venezuelan state was constituted as a site for shoring up political power and amassing personal wealth. (This is further discussed in Chap. 10.) As a negative mirror image of the bureaucratic Weberian ideal type, the Venezuelan public servant was perceived of as being unresponsive and unaccountable to public service, and with an explicit class bias excluding the popular sectors. People intuitively attributed the state a strong ability to reproduce this kind of behavior (or habitus, one could say); once people got on the inside of the state system, they were caught up in the inner logics and behavioral expectations inscribed in the state system. To the popular sector, their struggle was thus a matter of challenging the cultural hegemony and accustomed practices inscribed in the state itself, at the same time as they battled against their own "fifth columnists"- the Boliburgesia and the endogenous right - and the old layers of the Venezuelan state from the Fourth Republic.

\section{Chávez’s Scolding}

The discrepancies between political ideals and realpolitik was far from lost on lawmakers, who were working on developing legislation in different arenas to facilitate popular participation in state politics. One member of the National Assembly, speaking on conditions of anonymity, expressed great concern over how the state institutions were managing their dayto-day contact with the communities, arguing that the institutions were still often circumscribing and manipulating popular power. He criticized the simplified vision of popular power that prevailed in state institutions (see Fernandes 2010 for an analysis of the neoliberal rationalities of the Venezuelan state), estimating success on the basis of the number of proj- 
ects developed and the money spent, rather than on the basis of an integrated vision of popular empowerment and increasing autonomy from the state:

My perception is that things are not going as they should, though we are ok if we measure the advancement of popular power through obras (projects), for the things that they do with the money that they solicit and are granted. Why ok? Because, for example, if they elaborate a project to construct 20 houses to improve the life quality of 20 families they may even stretch the money to constructing 23-34 houses, they are efficient in that way. But this is not the kit of the revolution, or in other words, the kit of the revolution is not that the pueblo administers the state's resources.

The revolution is about people governing in an integrated manner, do you understand? [The idea about the revolution] is developed from an endogenous point of view, to improve their life conditions, to establish a system of communal economy that makes them less dependent on minimas publicas (public grants) and which helps them to construct a socialist society of equity, justice and rights ... that is why I cannot measure the advancement of popular power [in money] ... and that seems like what they are doing now, they measure it in the amounts transferred, but the money is just a resource that is justified by the projects, but the real benefit is in the achievements, in that the projects are generating the happiness of people, and not the money for the money's sake. That is my preoccupation.

This was in 2010, when the communal councils were a key focus area for the government. The deputy attributed much of the problems related to the implementation of these to the internal politics and culture of el Frente Francisco de Miranda, who was put in charge of managing the ministry and corresponding institutions responsible for working with the poder popular. El Frente, as it was normally called, was led by Erika Farías, a woman originally from Catia, a popular neighborhood in the west, who slowly, but surely, had climbed the ranks within the Bolivarian revolution. Many complained that under her, el Frente had been streamlined into a highly hierarchical and politically partisan organization, which had also made it lose its original appeal to young people from different political backgrounds and with different political viewpoints. Moreover, Farías was said to be an astute politician with a talent for securing her own power base, which translated into a very hierarchically organized ministry with institutions run by people loyal to her.

People often pondered over whether Chávez was informed well enough of what was going on, and most concluded that he wasn't. People thought 
that he was too trusting of his government ministers and therefore failed to pick up on what was going on within governmental institutions and "on the ground." As one man commented: "Lo tienen engañado" [they have him fooled]. In November 2009, it seemed as if the news of popular discontent over how the institutions were working had also reached Chávez. In a live episode of Aló Presidente, he subtly, but firmly, interrogated Erika Farías about what was going on in her ministry, and lashed out on the "bureaucratism" that was creating obstacles to people's efforts in organizing themselves. Even if people were used to Chávez interrogating ministers in public, after the live show, it was obvious that he was well-informed and upset about the problems between the public institutions and the communal councils, and sending Farías a not-so-subtle message about putting her own house in order. After that, Farías wasn't seen publicly for some weeks, and the institutions started to frenetically engage with the communal councils and approve projects that had been lingering for a long time.

This episode presents, very clearly, the image people had of Chávez as the embodiment of government power, yet incapable of actually controlling the state itself. People often said they felt sorry for Chávez who wanted to do so much good, but was sabotaged by the people that should have been working for him. That also explains why people like Adrian and Miche were fighting as best they could. In spite of the difficulties within the institutions, they felt that if ideologically committed people gave up and resigned, the state would be left to demagogic, opportunist and selfserving people who would make the revolution wither away from within.

\section{The Opaqueness of the State}

Caracas, 2011: One Thursday evening, I show up at seven o'clock in order to attend the meeting in the communal council. I had just come back to Venezuela after a year in Norway. When I had first spent time with them a year ago, they were about to get the communal council up and going. At the same time, there was also a lot of buzz around the new municipality's flagship program, Plan Caracas Socialista. This was a plan for urban rehabilitation of barrio communities, which would be developed in close co-operation by the municipal government and popular sector organizations. La Cañada would be the pilot project for the plan. For that purpose a gabinete sectorial had been organized-a coordinating forum for the different community organizations in this area. The municipal- 
ity also designed an enlace parroquial (a person that would co-ordinate municipality and community organizations).

I find the group outside the headquarters of the local colectivo. Last time I saw them, when they were about to organize the communal council, they were holding meetings at the local school, located next to one of the bloques. Then, 15 to 20 people were attending. Now it's only 5 to 6 , most of them the same community activists that have been gathering since long back.

As we wait for Roberto, the undisputed leader of the group, to sit down so we can start the meeting, I ask Irene about how things have been and how the work is coming along. She sighs and shakes her shoulders: "There is a lot of apathy in the community," she says. I ask about Plan Caracas Socialista and she answers that they didn't fulfill their promises. They did a bad job, and continued in the Zona Central before they finished here. "Jorge Rodriguez didn't show his face again," she says, referring to the kick-off meeting that they had with Jorge Rodriguez last year, when he promised that Plan Caracas Socialista would be the Municipal flagship program and that he would personally see to it. At the time it was even said that the mayor was taking secret trips to the area at night in order to see how things were proceeding.

Irene says that they have been sending letters to the Alcaldia and have tried to talk to them, but to no avail. Now Fundacaracas has taken over. As always, money is the issue; she sighs and shakes her head as in, "what can you do?" "It ended up being a white elephant," she says dryly.

But this week she has been called up by Fundacomunal. Suddenly they got a plumbing project approved. Fundacomunal had demanded to have some papers about the communal council saying that "they should have had them yesterday." Irene sighs again over this, because this whole process means that she has to open a new bank account, as Fundacomunal made their deposits in a different bank from that of the municipality. That meant that the whole process of paper work would have to be done all over again. "Why can they not just use the same bank account?" she complains again. Marta, a short woman in her 60s with indigenous traits, also comments on how difficult it is and how little help they feel that they are getting. She does however feel that the barrios are getting more help than the blocks, and she wonders if this is because they are in more dire need of help. However, both of them agree that they are a bit worn out in general. It feels like they have to knock on doors and hunt down decision-makers and decisions and information all the time and they just don't have time for that. 
People knew from experience that their everyday interaction with the state was precarious. The state could suddenly "withdraw" and make itself unavailable, projects could stop, employees could say one thing and do another, meetings could be canceled, personnel could be changed, money could run dry and political processes could be sabotaged. Rumors and speculations abounded about what was going on within different government ministries and different institutions, who were on their way out and who were on their way in in executive and public positions, which decisions Chávez was pondering, and which funds were being released somewhere in the system.

The people I met with on that Thursday evening knew that they were subject to a series of abstract decision-making processes that went beyond their comprehension and reach. In an article from South Africa, Jensen (2001) describes how failed security reforms in the post-apartheid regime was attributed to remaining agencies of the apartheid's security apparatus, called the Third Force. Over time, Third Force became more a concept than a reference to a specific agency, or what Laclau calls "an empty signifier" (Jensen 2001:117). The "Third Force" functioned as a catch-all explanatory narrative of struggle "where everything working against "the people' is placed" (Jensen 2001:117). In a similar fashion, popular sector activists kept referring to "the bureaucracy" and "the institutions"-the key "catch-all explanatory narratives" which were constantly invoked as the reasons for everything that went wrong and their frustrating challenges with the state bureaucracy.

\section{The Penetrable State}

To a certain extent, these notions reflected an imagery of the state as a monolithic site of diffuse but palpable governmentality. By making people wait, by keeping people in the dark, and by suddenly making decisions taking people by surprise, state institutions demonstrate their power (Auyero 2011). However, to paraphrase Gupta (1995:229), it is an analytical question when and under which conditions the state does appear as a cohesive and unitary whole. Accordingly, I will suggest that "seeing the state" (Scott 1999) as an enclosed site of power did not preclude that they also saw it and knew it for what it was: an incoherent apparatus of uncoordinated institutions and organs, of personal fiefdoms and hierarchical networks, of fragmented and incomplete information. For that reason, people continued to push their case, make phone calls, draw on contacts, 
and write letters (while others got frustrated and worn out). Like in the case of the CDI in Chap. 5, suddenly a door could open, the right buttons could be sufficiently pushed, the right person could get interested, Chávez or a minister could say or do something decisive, or the insistence and continuous presence of those involved was enough for the state to be engaged once more. In her case study of peasant organizations and the state in Mexico, Monique Nuijten (2003) argues that the efforts to connect with the state seldom pay off. In Venezuela, the picture wasn't that gloomy. Often, efforts to connect with the state, via formal or informal channels, did pay off, even though it required a lot of efforts.

As Grindle and Nuijten's note for Mexico, the state apparatus is so vast that most people "know someone" within the bureaucracy who can be mobilized. Grindle reports that most middle-class people have held a position in a political or governmental office at some point in their life, or they have had a family member or compadre in one (Grindle 1977:56, cited in Nuijten 2003:154). In the case of Venezuela, an increasing number of popular sector families now also had family, friends or relatives holding a position in political or governmental offices. Furthermore, the political alignment between the government and popular sector activists implied that, over the years, strategic bonds and alliances had been forged between state officials and local communities. Often, state and political officials appeared in public meetings where they could be approached, and the ideological ethos of popular power provided community activists with a discursive and political leverage. All in all, these changes made the state potentially accessible - if they were able to get a foot in the door.

Carmen, a community activist in 23 de Enero, expressed these efforts "to find a way in" in a very matter-of-fact way one evening, when we were talking on a basketball field while we waited for a meeting in the community council to start. She and her friend Belkis had been the pioneers of community work in their area, and their first project had been to fix the basketball court, complete with a mosaic of Bolívar, that we were standing on. "But I was practically stalking (former mayor of Caracas) Barreto to get the money," she said. At every public meeting Barreto held, she tried to give him a letter or talk to him. She explained that they had just gotten word that the money was within reach, when there was a change of administration, and the other guy ${ }^{6}$ took office, "and you know," she sighed. Eventually, they managed to get money for the project from the Libertador Municipality, with the help of a local and well-connected resident. 


\section{DraWING ON NETWORKS}

It is not my intention to suggest that the political and state institutions did not initiate and carry out projects and policies in shantytown communities on their own account or that the communal councils did not have their project approved unless they were able to hunt down significant politicians or state bureaucrats. However, what I want to highlight is that the ability to push the right "state buttons" is a central factor for explaining why bottom-up initiated community politics unfolded in such a heterogeneous manner in different areas. As we will learn more in the following chapter, a community council's ability to push their project through depended to a certain extent on the capacity and conscientiousness of the public official that had been assigned to help them in the process. The community's own organizational strength and "social capital" was also shaping their ability to access state funds and strengthen their political momentum. Moreover, the state institutions also at times identified "priority areas" that were assigned particular attention.

To illustrate this point, I'll use the example of a meeting with a colectivo in 23 de Enero. The colectivo was having a meeting to organize a gran mega jornada integral. Jornada is a term describing a fair where different government services and products are present. For example, jornadas of large-scale sales of food, through the distribution chain Mercal, are occasionally organized in open public spaces, especially before Christmas. This gives people the opportunity to do their Christmas shopping (a major cost for lower-income families) at discounted prices. For this local mega jornada, they were planning on having military enrollment opportunities arranged, free vaccines, sale of the new government-produced mobile telephone, Vergatario, a stall where people could issue new cedulas (identity cards) and sale of food through Mercal. They also wanted to arrange a salsa concert in the evening, and had invited one of the musicians from Grupo Madera (a famous band that has also made "jingles" for the government) to join the meeting. The musician present from Grupo Madera said that the group would be happy to participate and that they were always in favor of working with the communities. Personally, he didn't work for the government, but he had friends that did and that could get a hold of the equipment for the event. "This is the political work that the government workers have to assume," the musician said. The group started to discuss whom they could use as a connection. "Deputy Chino Jose Khan is responsible for this area," the musician said. Giorgio, the 
leader of the local colectivo, answered that he had his telephone number. He had tried calling him, but the deputy had not answered. He had also tried to call Valentin, the influential leader for the colectivo La Piedrita, for two months, but he hadn't picked up either. The musician mentioned that he knew the deputy's assistant, Carmencita, to which Giorgio responded that they knew her as well, but that "she has forgotten one's face." They then mentioned Robert Serra (who was later brutally murdered), another of the deputies with close bonds to 23 de Enero, and Giorgio said that he would be responsible for making contact with him. They then agreed that they still needed to find a way to get a hold of Chino Khan.

As this ethnographic example shows, people draw from the mechanisms that have always characterized the informal dynamics of the Venezuelan state apparatus, using personal contacts and finding ways to engage central decision-makers. In many ways people take it for granted that "this is the way things work." At the same time, as we will discuss further below, people's expectations for state accessibility and accountability, or what in Venezuelan terms is dar respuestas (give answers), was increasing as community self-consciousness, and the political ethos of popular power, translated into a redefined vision of what the state, and its representatives, should act like. These changing expectations constituted one of the key levels of negotiation that shaped the interaction between communities and state and government bodies.

Some activists complained that 23 de Enero (where the example above is taken from) received an un-proportional amount of government attention and resources, not only because its fame and relative proximity to the city center gave it a status as a "showcase community," but also because its residents were well-connected through political networks dating long back. To a certain extent this is true; 23 de Enero was granted several large projects and did have its public services significantly expanded. On the other hand, this also happened because the grassroots networks and organizations were organizationally prepared to collaborate with the state institutions - though organizational capacities were distributed unevenly across the community. In spite of the state apparatus' frequently fallible and erratic maneuvers, there was also a keen understanding of the importance of nurturing popular power in an organic and gradual manner. If money and projects were assigned to communities that were organizationally unprepared, money would be squandered and the projects would fall apart. At the same time, the state also was organizationally and politically deficient in following their politics and policies through. As we will discuss 
further in Chap. 7, the implementation of new public policies and political directives was therefore guided by careful considerations of what was organizationally and politically feasible, as well as the messy and often contradictory realities of the political game and state action.

\section{INSTITUTIONAL INERTIA}

In an article from South Africa, Jensen poses the question of how a political party can bring about reforms at the level of the state (2001:97). As the African National Congress (ANC) swept to power in 1994, the party was determined to use the state as an instrument for a complete overhaul of society. The South African and Venezuelan cases have similarities. First, the ANC perceived the state as a tool to be deployed by a political party in order to promote the interests of the people. Second, the perception of the "old state" was one of an apparatus designed to protect the interests of a minority (the white in the South African case, the bourgeois and the elites in the Venezuelan case), providing the newcomers with the legitimate right to rule and reform the state. However, as Jensen demonstrates, political reforms were not enacted in the form that the ANC had envisioned. Rather, transformations came about "through very localized, not always heroic, power struggles" (Jensen 2001:97). He argues that "bureaucratic knowledge and experience inscribed in institutional practices produce inertia within institutions that are very difficult to change" (Jensen 2001:107).

This is an observation that can very easily be applied to the Venezuelan case. By looking at the state bureaucracy we realize that the state is not guided by a single coherent political line, but rather consists of a multitude of overlapping, contested and unbounded fields. There are often enormous contradictions and discrepancies between the government's political vision and its ability to implement it. While governments may aim at creating a new state order with institutions that respond to the citizens' needs and the implementation of new legislation, it may be hard to put such political ambitions and directives into practice. Transformation takes place in a number of arenas, through a multitude of everyday struggles, with conflicting interests and shifting alliances within, outside and between the realms of the state and the realms of the popular sector. It leads to the formation of new social relations and new configurations of power and alliances that aren't necessarily in accordance with the new political discourse, and where individual interests compete with visions of collective change. 
In Chap. 7, we will explore how people were actively contesting the hierarchical nature and cultural hegemony inscribed in the Venezuelan state. Drawing on the political, social and cultural knowledges and socialities of the popular sectors, people were trying to push state and political actors into complying with the Bolivarian ethos of a popular takeover of the state. I will start by exploring the role of the so-called promotores integrales-public officials assigned to work closely with popular sector communities through the communal council. I will argue that their role took place within a hybrid interface (Long 1999) ${ }^{7}$ where "state power" and "popular power" met on a day-to-day basis, carving out a negotiated and contested space for popular sector politics within the realm of the state.

\section{Notes}

1. Misión Identidad was a program designed to give identity documents to all citizens, including foreigners living undocumented in the country. The program was carried out by visiting remote areas with mobile units and setting up temporary offices throughout the country.

2. See also Joseph and Nugent (1994), Nugent (1997, 1998), Starn (1999) for explorations of Latin American state formations.

3. Chávez's bid for constitutional reforms in 2007 represented a quest for gaining popular approval for radical reforms-a proposal that the electorate turned down with a narrow margin.

4. Although this is a publicly known event, I have chosen not to go into details about the office and individuals involved. This account is the result of interviews and conversations with various people close to the center of events.

5. La Guaira is the coastal strip around the airport Maiquetia.

6. Juan Barreto was followed by Antonia Ledezma, who represents the opposition.

7. Long describes interfaces as "point where different, often conflicting, lifeworlds or social fields intersect, or more concretely, in social situations or arenas in which interactions become oriented around problems of bridging, accommodating, segregating or contesting social, evaluative and cognitive standpoints" (Long 1999:1).

\section{BIBLIOGRAPHY}

Abrams, Philip. 1988 [1977]. Notes on the Difficulties of Studying the State. In The Anthropology of the State. A Reader, ed. A. Sharma and A. Gupta. Oxford: Blackwell Publishing. 
Auyero, Javier. 2011. Patients of the State: An Ethnographic Account of Poor People's Waiting. Latin American Research Review 46 (1): 5-29.

Bourdieu, Pierre. 1979. Distinctions. A Social Critique of the Judgment of Taste. Cambridge, MA: Harvard University Press.

- 1986. The Forms of Capital. In Handbook of Theory and Research for the Sociology of Education, ed. J. Richardson. New York: Greenwood.

Crehan, Kate A.F. 2002. Gramsci, Culture and Anthropology. Berkeley: University of California Press.

Fernandes, Sujatha. 2010. Who Can Stop the Drums? Urban Social Movements in Chávez' Venezuela. Durham and London: Duke University Press.

Foucault, Michel. 1991. Governmentality. In The Anthropology of the State. A Reader, ed. A. Sharma and A. Gupta. Oxford: Blackwell Publishing.

Frente Francisco de Miranda. n.d. Que es el Frente. http://frentefranciscodemirandasocopo.blogspot.no/p/quienes-somos.html. Accessed February 20, 2017.

González, Rafael Gustavo. 2013. La palanca. Aporrea, June 20. http://www. aporrea.org/actualidad/al69067.html. Accessed February 20, 2017.

Gupta, Akhil. 1995. Blurred Boundaries: The Discourse of Corruption, the Culture of Politics, and the Imagined State. In The Anthropology of the State. A Reader, ed. A. Sharma and A. Gupta. Oxford: Blackwell Publishing.

Hansen, Thomas Blom, and Finn Stepputat. 2001. Introduction: States of Imagination. In States of Imagination. Ethnographic Explorations of the Postcolonial State, ed. T.B. Hansen and F. Stepputat. Durham and London: Duke University Press.

Jensen, Steffen. 2001. The Battlefield and the Prize: ANC's Bid to Reform the South African State. In States of Imagination. Ethnographic Explorations of the Postcolonial State, ed. T.B. Hansen and F. Stepputat. Durham and London: Duke University Press.

Joseph, Gilbert M., and Daniel Nugent. 1994. Everyday Forms of State Formation. Revolution and Negotiation of Rule in Modern Mexico. Durham and London: Duke University Press.

Krohn-Hansen, Christian, and Knut G. Nustad. 2005. Introduction. In State Formation. Anthropological Perspectives, ed. C. Krohn-Hansen and K.G. Nustad. London and Ann Arbor, MI: Pluto Press.

Lazar, Sian. 2008. El Alto, Rebel City. Self and Citizenship in Andean Bolivia. Durham and London: Duke University Press.

Long, Norman. 1999. The Multiple Optic of Interface Analysis (Working Title). UNESCO Background Paper on Interface Analysis, October. http://lanic. utexas.edu/project/etext/llilas/claspo/workingpapers/multipleoptic.pdf. Accessed February 20, 2017.

Mauss, Marcel. 1954. The Gift: Forms and Functions of Exchange in Archaic Societies. New York: W.W. Norton. 
Mitchell, Timothy. 2006 [1999]. Society, Economy and the State Effect. In The Anthropology of the State. A Reader, ed. A. Sharma and A. Gupta. Oxford: Blackwell Publishing.

Neuman, Iver. 2005. 'A Speech That the Entire Ministry May Stand For': On Generating State Voice. In State Formation. Anthropological Perspectives, ed. C. Krohn-Hansen and K.G. Nustad. London and Ann Arbor, MI: Pluto Press. Nugent, David. 1997. Modernity at the Edge of Empire. State, Individual and Nation in the Northern Peruvian Andes, 1885-1935. Stanford, CA: Stanford University Press.

Nugent, Daniel. 1998. Rural Revolt in Mexico, U.S. Intervention and the Domain of Subaltern Politics. Durham and London: Duke University Press.

Nuijten, Monique. 2003. Power, Community, and the State. The Political Anthropology of Organization in Mexico. London and Sterling, VA: Pluto Press. Scott, James. 1985. Weapons of the Weak. Everyday Forms of Peasant Resistance. New Haven and London: Yale University Press.

- 1999. Seeing Like a State: How Certain Schemes to Improve the Human Condition Have Failed. New Haven and London: Yale University Press.

Sharma, Aradhana, and Akhil Gupta. 2006. The Anthropology of the State: A Reader. Oxford: Blackwell Publishing.

Starn, Orin. 1999. Nightwatch. The Politics of Protest in the Andes. Durham and London: Duke University Press.

Thomassen, Bjørn. 2012. Notes towards an Anthropology of Political Revolutions. Comparative Studies in Society and History 54 (3): 679-706.

Valencia, Cristobal. 2015. We Are the State! Barrio Activism in Venezuela's Bolivarian Revolution. Tucson: The University of Arizona Press.

Wolf, Eric. 1990. Distinguished Lecture: Facing Power-Old Insights, New Questions. American Anthropologist 92 (3): 586-596.

Open Access This chapter is distributed under the terms of the Creative Commons Attribution 4.0 International License (http://creativecommons.org/ licenses/by/4.0/), which permits use, duplication, adaptation, distribution and reproduction in any medium or format, as long as you give appropriate credit to the original author(s) and the source, provide a link to the Creative Commons license and indicate if changes were made.

The images or other third party material in this chapter are included in the chapter's Creative Commons license, unless indicated otherwise in a credit line to the material. If material is not included in the chapter's Creative Commons license and your intended use is not permitted by statutory regulation or exceeds the permitted use, you will need to obtain permission directly from the copyright holder.

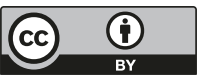

